\title{
Binding of amelogenin to MMP-9 and their co-expression in developing mouse teeth
}

\author{
Junsheng Feng • Jennifer S. McDaniel • Hui-Hsiu Chuang • Ouwen Huang • \\ Audrey Rakian - Xiaoping Xu • Bjorn Steffensen - Kevin J. Donly • \\ Mary MacDougall $\cdot$ Shuo Chen
}

Received: 8 March 2012/ Accepted: 29 April 2012/Published online: 31 May 2012

(C) The Author(s) 2012. This article is published with open access at Springerlink.com

\begin{abstract}
Amelogenin is the most abundant matrix protein in enamel. Proper amelogenin processing by proteinases is necessary for its biological functions during amelogenesis. Matrix metalloproteinase 9 (MMP-9) is responsible for the turnover of matrix components. The relationship between MMP-9 and amelogenin during tooth development remains unknown. We tested the hypothesis that MMP-9 binds to amelogenin and they are co-expressed in ameloblasts during amelogenesis. We evaluated the distribution of both proteins in the mouse teeth using immunohistochemistry and confocal microscopy. At postnatal day 2, the spatial distribution of amelogenin and MMP-9 was co-localized in preameloblasts, secretory ameloblasts, enamel matrix and odontoblasts. At the late stages of mouse tooth development, expression patterns of
\end{abstract}

Junsheng Feng and Jennifer S. McDaniel contributed equally to this work.

J. Feng · J. S. McDaniel · H.-H. Chuang · O. Huang ·

A. Rakian · K. J. Donly $\cdot$ S. Chen ( $₫)$

Department of Developmental Dentistry, The University

of Texas Health Science Center at San Antonio,

7703 Floyd Curl Dr., San Antonio, TX 78229-3900, USA

e-mail: chens0@uthscsa.edu

J. Feng

Department of Anatomy and Histoembryology, Fujian Medical University, Fuzhou 350018, China

X. Xu · B. Steffensen

Department of Periodontics, The University of Texas Health

Science Center at San Antonio, San Antonio, TX 78229, USA

M. MacDougall

Department of Oral/Maxillofacial Surgery, School of Dentistry, University of Alabama at Birmingham, Birmingham,

AL 35294, USA amelogenin and MMP-9 were similar to that seen in postnatal day 2. Their co-expression was further confirmed by RT-PCR, Western blot and enzymatic zymography analyses in enamel organ epithelial and odontoblast-like cells. Immunoprecipitation assay revealed that MMP-9 binds to amelogenin. The MMP-9 cleavage sites in amelogenin proteins across species were found using bioinformative software program. Analyses of these data suggest that MMP-9 may be involved in controlling amelogenin processing and enamel formation.

Keywords Amelogenin · MMP-9 - Co-expression · Protein interaction $\cdot$ Ameloblasts

\section{Introduction}

Dental enamel is formed by ameloblasts originally derived from embryonic oral epithelium. The differentiation of dental epithelium into functional ameloblasts occurs in spatial-temporal patterns during tooth development and these ameloblasts synthesize and secrete enamel matrix proteins. Amelogenin is the most abundant enamel matrix protein, accounting for about $90 \%$ of total enamel organic matrix. This gene was cloned and characterized from the teeth of bovine, porcine, rat, mouse and human (Snead et al. 1983; Takagi et al. 1984; Gibson et al. 1991a; Nakahori et al. 1991; Salido et al. 1992; Bonass et al. 1994; Hu et al. 1996; Diekwisch et al. 1997). It is synthesized in a distinct time frame during amelogenesis. In mice, amelogenin gene expression was identified in ameloblasts and enamel matrix from embryonic day 15 to postnatal day 14 (Snead et al. 1988; Couwenhoven and Snead 1994; $\mathrm{Hu}$ et al. 2001; Iacob and Veis 2006). Rat amelogenin expression was also characterized in teeth from embryonic 
day 18.5 to postnatal day 15 as well as the continuously erupting incisors at the later stages (Fong et al. 1996; Inage et al. 1996; Bleicher et al. 1999). In developing hamster teeth, amelogenin expression was identified in pre-ameloblasts, secretory, transition, and early maturation stage ameloblasts and in the enamel matrix (Karg et al. 1997). A similar expression pattern was observed in pig teeth except for ameloblasts after the transition stage (Wakida et al. 1999). Originally, amelogenin was thought to be expressed solely by ameloblasts during tooth development (Snead et al. 1988; Inai et al. 1991; Karg et al. 1997; Hu et al. 2001). Recently, it has been found that this gene is also expressed in odontoblasts and other tissues (Veis et al. 2000; Oida et al. 2002; Nagano et al. 2003; Papagerakis et al. 2003; Iacob and Veis 2006; Haze et al. 2007). Amelogenin plays a critical role in the structural organization of enamel as well as in mineralization (Deutsch et al. 1995; Bartlett and Simmer 1999). Amelogenin gene mutations in humans and mice cause amelogenesis imperfecta (AI), one of the most common enamel genetic diseases (Lagerström et al. 1991; Aldred et al. 1992; Gibson et al. 2001; Wright et al. 2011).

Large-molecular-mass amelogenin proteins as well as small-molecular-mass amelogenin polypeptides have been isolated and characterized in different species teeth during the process of development and mineralization (Bronckers et al. 1995; Boabaid et al. 2004). The biochemistry and biological roles of these different fragments in enamel formation and biomineralization have been studied (Gibson et al. 1991b; Le et al. 2007; Warotayanont et al. 2008; Nakayama et al. 2010; Pugach et al. 2010). It is known that amelogenin requires processing by proteinases to activate functional domains (Fincham and Moradian-Oldak 1993). For instance, matrix metalloproteinase 20 (MMP-20) and kallikren 4 (Klk4) are expressed in ameloblasts during amelogenesis and are capable of catalyzing enamel matrix proteins including amelogenin ( $\mathrm{Li}$ et al. 1999; Ryu et al. 1999; Bourd-Boittin et al. 2004; Sun et al. 2010; Uskoković et al. 2011). These two proteinases are critical for enamel matrix processing. MMP-20 and Klk4 gene mutations in humans and mice cause hypomaturation AI (Caterina et al. 2002; Hart et al. 2004; Kim et al. 2005; Simmer et al. 2009).

Matrix metalloproteinase 9 (MMP-9), also known as gelatinase B or type IV collagenase, belongs to a member of the MMP gene family and is expressed in ameloblasts and odontoblasts as well as other dental cells during tooth development (Tjäderhane et al. 1998; Sahlberg et al. 1999; Randall and Hall 2002; Goldberg et al. 2003; Palosaari et al. 2003; Yoshiba et al. 2003; Takahashi et al. 2006; Paiva et al. 2009; Gomes et al. 2011). This enzyme is involved in bone resorption and degradation of the basement membrane during tooth development as well as extracellular matrix (ECM) turnover in association with tooth eruption (Linsuwanont et al. 2002; Basi et al. 2011). MMP-9 has a broad range of substrate specificity including native collagenous and non-collagenous proteins as well as non-structural ECM components (Vu et al. 1998; Kridel et al. 2001; Somerville et al. 2003; Nagase et al. 2006). However, the entire assortment of substrates for the MMPs has not been fully elucidated. MMP inhibitors were used to treat mouse tooth germs, resulting in impairment of murine amelogenesis (Fanchon et al. 2004; Bourd-Boittin et al. 2005). Furthermore, bone deficiency was observed and osteoblast apopotosis was increased in MMP-9 knock out mice (Vu et al. 1998). Our previous study showed that abnormal tooth morphology, immature ameloblast differentiation, and loss of ameloblast polarization occur in MMP-9 null mice (Yuan et al. 2009, unpublished data). Although expression of both amelogenin and MMP-9 during tooth development was described, their relationship in tooth formation has not been observed. In the present study, we were interested in the interaction between amelogenin and MMP-9 as well as comparing the spatialtemporal distribution of both proteins during mouse tooth development. We hypothesized that interactions between amelogenin and MMP-9 as well as developmental changes in the spatial distribution of these two proteins might exist. To test these hypotheses, we designed experiments to examine the binding of MMP-9 to amelogenin. We further analyzed the distribution of amelogenin and MMP-9 at the same stages of mouse tooth development. Our studies indicated that MMP-9 binds to amelogenin and they are co-expressed in ameloblasts in developing mouse teeth. Furthermore, computational data analysis indicated that potential cleavage sites of MMP-9 exist in amelogenin across different species.

\section{Materials and methods}

Animals and tissue preparation

All experimental procedures involving the use of animals were approved by the University of Texas Health Science Center at San Antonio (UTHSCSA), TX. ICR mice were purchased from Harlan-Laboratory Animals Inc. (Indianapolis, IN, USA). The MMP-9 knock out mice were obtained from the Jackson Laboratory (Bar Harbor, Maine, USA). For developmental studies, mice with litters of embryonic stage E18.5 and postnatal days 2, 5 and 7 were sacrificed. Mouse tissues were dissected and fixed in $4 \%$ paraformaldehyde overnight. After demineralization in $15 \%$ EDTA, samples were dehydrated in increasing concentrations of ethanol, embedded in paraffin, sectioned, and prepared for immunohistochemistry analysis. 


\section{Cell culture}

Mouse odontoblast-like cells (MO6-G3) were grown at $33{ }^{\circ} \mathrm{C}$ under $5 \% \mathrm{CO}_{2}$ in alpha minimum essential medium $(\alpha$-MEM) supplemented with $10 \%$ fetal calf serum, $100 \mathrm{units} / \mathrm{ml}$ penicillin/streptomycin, $50 \mu \mathrm{g} / \mathrm{ml}$ ascorbic acid, and $10 \mathrm{mM} \mathrm{Na} \beta$-glycerophosphate (Sigma, St. Louis, MO, USA). The mouse enamel organ epithelial (EOE-3M) cell line was maintained in Dulbecco's modified eagle medium (DMEM) (Gibco, Grand Island, NY, USA) with $10 \%$ fetal calf serum, 100 units $/ \mathrm{ml}$ penicillin/ streptomycin, $50 \mu \mathrm{g} / \mathrm{ml}$ ascorbic acid.

RNA preparation and reverse transcription-polymerase chain reaction (RT-PCR)

Total RNA was extracted from mouse teeth and MO6-G3 and EOE-3M cell lines by using RNA STAT-60 kit (TelTest, Inc. Friendswood, TX, USA), treated with DNase I (Promega, Madison, WI, USA), and purified with the RNeasy Mini Kit (Qiagen Inc., Valencia, CA, USA). RNA concentration was determined at an optical density of $\mathrm{OD}_{260}$. The RNA was transcribed into cDNA by SuperScript II reverse transcriptase (Invitrogen, Carlsbad, CA, USA). For PCR analysis, specific primers of mouse amelogenin and MMP-9 were synthesized as follows: mouse amelogenin, forward $5^{\prime}$-TGAAGTGGTACCAGAGCA-3' and reverse $5^{\prime}$-ACAGGGATGATTTGGTGGTG-3'; MMP9, forward $5^{\prime}$-CAGACCAAGAGGGTTTTCTT- $3^{\prime}$ and reverse CTTGTTCACCTCATTTTGGA- $3^{\prime}$. The PCR reaction was first denatured at $95{ }^{\circ} \mathrm{C}$ for $5 \mathrm{~min}$, and then carried out at $95{ }^{\circ} \mathrm{C}$ for $30 \mathrm{~s}$, at $55-60{ }^{\circ} \mathrm{C}$ for $30 \mathrm{~s}$ and at $72^{\circ} \mathrm{C}$ for $60 \mathrm{~s}$ for 35 cycles and with a final $10 \mathrm{~min}$ extension at $72{ }^{\circ} \mathrm{C}$. Five $\mu \mathrm{l}$ of PCR products were analyzed using agarose gels and ethidium bromide staining. Corrective DNA was verified by DNA sequencing.

Expression and purification of recombinant proteins

The full-length mouse amelogenin gene was amplified by PCR using mouse tooth cDNA as a template with primers adding Xho I and Not I sites for directional ligation into the expression vector pGEX-6P1 with Xho I and Not I sites (Amersham Pharmacia Biotech, Piscataway, NJ, USA) and named pGST196 (amino acids ${ }^{1-196}$ ). The pGST196 expression and purification was performed according to the manufacturer's instruction (Amersham Pharmacia Biotech). The recombinant, untagged murine amelogenin (rM179, amino acids ${ }^{18-196}$ ) was subcloned into pET11a vector with $N d e l$ and $B a m H$ I sites (Novagen, Madison, WI, USA) and termed pET179. This pET179 vector was kindly provided by Dr. Simmer (The
Department of Biological and Materials Sciences, University of Michigan School of Dentistry, Ann Arbor, MI, USA). A recombinant amelogenin protein was expressed and purified as described previously (Simmer et al. 1994). Recombinant mutant MMP-9 (rMut-MMP-9) construct was generated as described previously (Xu et al. 2005). Briefly, to obtain rMut-MMP-9 with intact ligand-binding properties but without catalytic activities, the active site $\mathrm{Glu}^{402}$ of proMMP-9 was substituted for alanine residue to generate MMP-9 ${ }^{\mathrm{E} 402 \mathrm{~A}}$ (Morgunova et al. 1999). The point mutation was introduced into the coding DNA by overlap-extension PCR using the following primer pairs: forward, 5'-GTGGCGGCGCATGCGTTCGGCCACGCG$3^{\prime}$, and reverse, 5'-CGCGTGGCCGAACGCATGCGCCG CCAC- $3^{\prime}$. The expression construct for MMP-9 in pRSETA vector served as a template in PCR reaction buffer that includes $5 \mu \mathrm{l}$ of $10 \times$ reaction buffer, $100 \mathrm{ng}$ of template DNA, $125 \mathrm{ng}$ of each primer, $25 \mu \mathrm{M}$ dNTP mixtures, and 2.5 units Pfu Turbo DNA polymerase. The cycles included $95{ }^{\circ} \mathrm{C}$ for $2 \mathrm{~min}$, then $95^{\circ} \mathrm{C}$ for $30 \mathrm{~s}$, $55^{\circ} \mathrm{C}$ for $1 \mathrm{~min}$ and $72{ }^{\circ} \mathrm{C}$ for $10 \mathrm{~min}$ for 12 cycles. Subsequently, $1 \mu \mathrm{l}$ of the DpnI restriction enzyme was added for $1 \mathrm{~h}$ at $37^{\circ} \mathrm{C}$ to digest the parental DNA. The pRESTA vector containing histidine tagged rMutMMP-9 gene was transformed into E. coli BL21 (DE3) competent cells and expressed and purified. A recombinant mouse MMP-9 protein was purchased from R\&D Systems Inc. (Minneapolis, MN, USA; Catalog No. 909-MM).

Glutathione fusion protein (GST) pull down assay

For probing protein-protein interactions, either the full length recombinant amelogenin protein tagged with GST (pGST196) or GST protein was incubated with the recombinant mutant MMP-9 protein in the lysis buffer (20 mM Tris- $\mathrm{HCl}$, pH 8.0, $200 \mathrm{mM} \mathrm{NaCl}, 1 \mathrm{mM}$ EDTA) overnight at $4{ }^{\circ} \mathrm{C}$ with end-over-end mixing. After the reaction, the glutathione agarose beads were added for further incubation. The samples were then centrifuged and the supernatant was removed. After extensive washes, the beads were mixed with an equal volume of $2 \times$ SDS-PAGE gel-loading buffer and then boiled for 4 min followed by SDS-PAGE and Western Blot analyses.

Western blot analysis

The proteins were loaded onto a $10 \%$ SDS-PAGE gel and transferred to a trans-blot membrane (Bio-Rad Laboratory, Inc., Hercules, CA, USA). Western blotting assay was carried out as described earlier (Chen et al. 2008). 


\section{Gelatin zymography}

Gelatinase activity of MO6-G3 and EOE-3M cells was determined by SDS-PAGE electrophoresis zymography. The supernatant of MO6-G3 and EOE-3M without serum treatment underwent electrophoresis without reduction on SDS-PAGE gels prepared with $7 \%$ acrylamide containing $0.1 \%$ gelatin. The SDS was removed by a 1-h incubation in $2.5 \%$ Triton $\mathrm{X}-100$, and the gels were then incubated in $30 \mathrm{mM}$ Tris- $\mathrm{HCl}$ (pH 7.4), $200 \mathrm{mM} \mathrm{NaCl}$, $5 \mathrm{mM} \mathrm{CaCl}_{2}$, and $1 \mathrm{mM} \mathrm{ZnCl} 2$ at $37{ }^{\circ} \mathrm{C}$ for overnight prior to being stained with Coomassie Brilliant Blue. Enzyme activity was visualized as zones of gelatin clearance.

\section{Immunohistochemistry}

Primary antibodies including a goat polyclonal anti-Amel (C-19), a rabbit polyclonal anti-Amel (FL-191), a goat polyclonal anti-MMP-9 (C-20) and a rabbit polyclonal anti-MMP-9 (H-129) were purchased from Santa Cruz Biotechnology, Inc. (Santa Cruz, CA, USA). The IHC experiments were performed using an ABC kit (Vector Laboratories Inc. Burlingame, CA, USA), according to the manufacturer's instructions. Either pre-immune rabbit or goat IgG instead of the first antibodies was used as a negative control (Dakocytomation, Carpinteria, CA, USA). For observation of co-expression of amelogenin and MMP9, the double-labeled immunostaining was carried out using two types of primary antibodies along with two types of fluorescent secondary antibodies. The tissue section was blocked with normal donkey serum (Sigma, St. Louis, MO, USA) for $60 \mathrm{~min}$ at room temperature and then incubated with one type of the primary goat polyclonal anti-amelogenin antibody, C-19, which was recognized by the donkey anti-goat secondary antibody conjugated with Alexa Fluo ${ }^{\circledR}$ 488 (Molecular Probes, Eugene, OR, USA) followed by incubation with a rabbit polyclonal antibody against MMP9, H-129, recognized by the donkey anti-rabbit secondary antibody conjugated with Alexa Fluo ${ }^{\circledR}$ 568. The immunostained section using the two types of antibodies was observed under the same parameters in a Nikon inverted microscope and quantitated by means of NIS-GIEMENTS software. For each experiment, all slides were simultaneously processed for a specific antibody, so that homogeneity in the staining procedure was ensured between the samples. After the capture of these images at the same magnification, the threshold was set and maintained for each slide in the experiment. The optical density was calculated by use of the morphometric analysis within the software package. Hoechst was used for nucleus staining and either normal rabbit or goat immunoglobulin (IgG) served as a negative control (Dakocytomation).

Confocal microscopic evaluation and image acquisition

Sections were evaluated with a Nikon Eclipse 90i C1si laser scanning confocal microscope (Nikon Instruments, Melville, NY, USA) with a 40X/1.30 N.A. oil immersion objective. This evaluation included the selection of a laser gain setting used to image $\mathrm{Na}_{\mathrm{v}} 1.6$-immunofluorescence to avoid saturated pixels so to allow a full dynamic range of $\mathrm{Na}_{\mathrm{v}}$ 1.6-immunofluorescence pixel intensity and to select laser gain settings used to image caspr staining.

Protein sequencing and data analyses

A database search was performed at the National Center for Biotechnology Information website (http://www.ncbi.nlm. nih.gov/blast) using the BLAST program. The amelogenin nucleotides and derived amino acids were aligned with those from different species using the Gene Runner software program (http://www.generunner).

\section{Results}

Expression of amelogenin and MMP-9 in mouse teeth

To determine the expression of the two genes in ameloblasts, we systematically evaluated the expression of amelogenin and MMP-9 in developing mouse teeth using immunohistochemistry assays. Amelogenin epitopes were highly localized in the pre-ameloblasts, secretory ameloblasts and enamel matrix at the postnatal day 2 (PN2) in mouse molars (Fig. 1b-d). MMP-9 expression overlapped with amelogenin in these regions and its signal was also present in the dental pulp cells, alveolar bone mesenchymal cells and stratum intermedium (Fig. 1e-g). At PN 5, amelogenin protein in secretory ameloblasts and enamel layer was strongly expressed, but low levels of expression were observed in odontoblasts and stratum intermedium (Fig. 2b-d). The spatial distribution pattern of MMP-9 was similar to amelogenin besides its expression in alveolar bone mesenchyme (Fig. 2f-h). Similar to PN 5, at PN7, amelogenin was highly expressed in secretory ameloblasts and enamel in developing molars, whereas its signal was weakly detected in odontoblasts (Fig. 3b-d). Compared to amelogenin, the MMP-9 gene was widely expressed although MMP-9 was also present in ameloblasts and odontoblasts (Fig. 3f-h).

To further study the co-expression of the two proteins in ameloblasts, their distribution profiles in developing mouse 


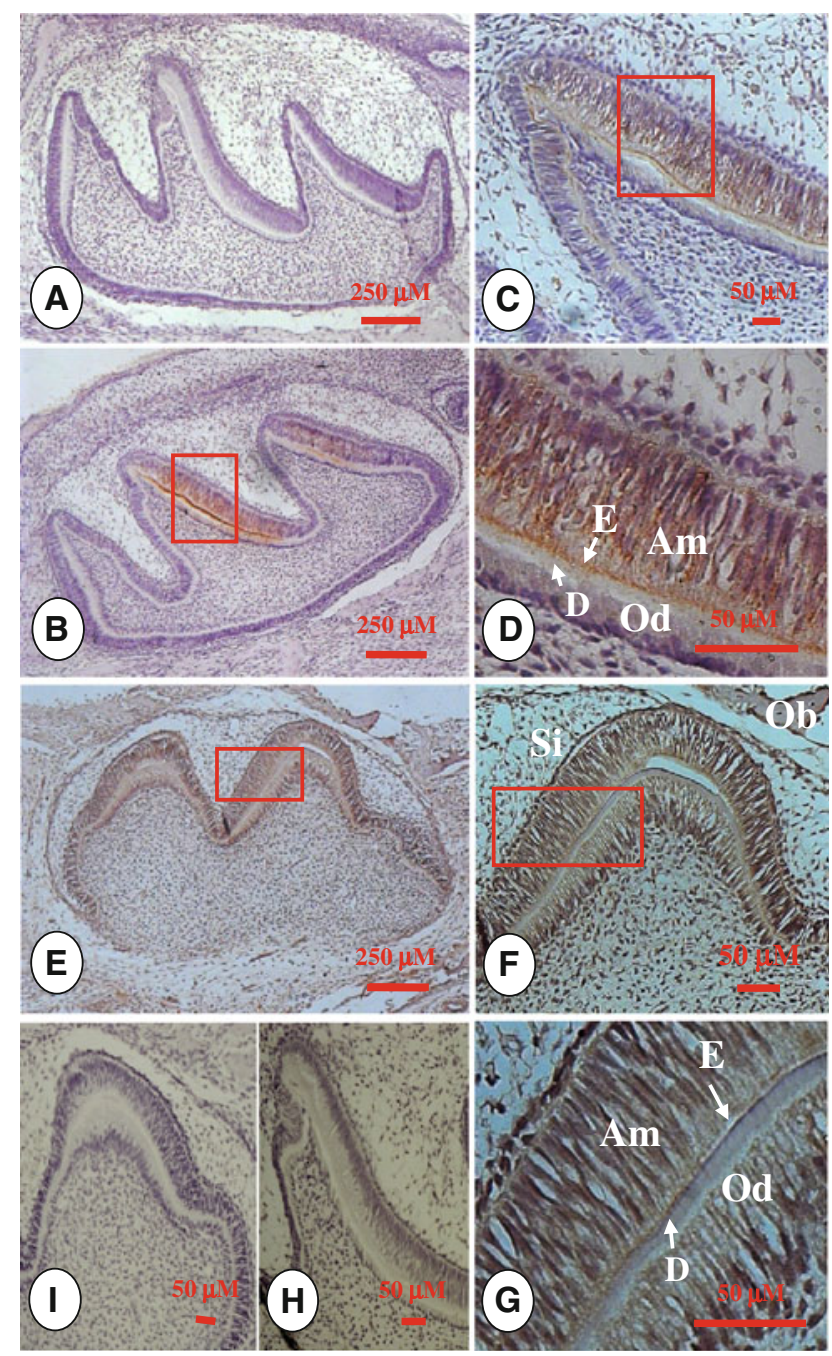

Fig. 1 Amelogenin and MMP-9 expression patterns at postnatal day 2 in developing teeth. b Amelogenin expression was observed in preameloblasts, ameloblasts, enamel matrix and odontoblasts at postnatal day 2 in mouse molars. $\mathbf{c}, \mathbf{d}$ were higher magnification of the boxed area in b. a Pre-immune IgG at the same concentration as antiamelogenin antibody was used as a negative control. e Mouse molar was stained with anti-MMP-9 antibody. $\mathbf{f}$, $\mathbf{g}$ show higher magnification of the boxed area in e. MMP-9 was widely expressed in bone mesenchymal cells, stratum intermedium, dental pulp, odontoblasts, ameloblasts and enamel matrix. i The section was stained with preimmune $\operatorname{IgG}$ as a negative control. $\mathbf{h}$ A tissue section from a MMP-9 knock out mouse was incubated with anti-MMP-9 antibody as control. Am ameloblasts, $D$ dentin, $E$ enamel, $O d$ odontoblasts, $O b$ bone mesenchymal cells, $S i$ stratum intermedium

teeth were examined using double labeling immunohistochemistry. Amelogenin protein in secretory ameloblasts was strongly expressed, and the signal intensity per cell was higher in enamel matrix (Fig. 4b, f). This protein in secretory ameloblasts was mostly located in the supranuclear area (towards the enamel), but was also present in the infranuclear region (away from the enamel). Amelogenin expression was also detected in odontoblasts, but its
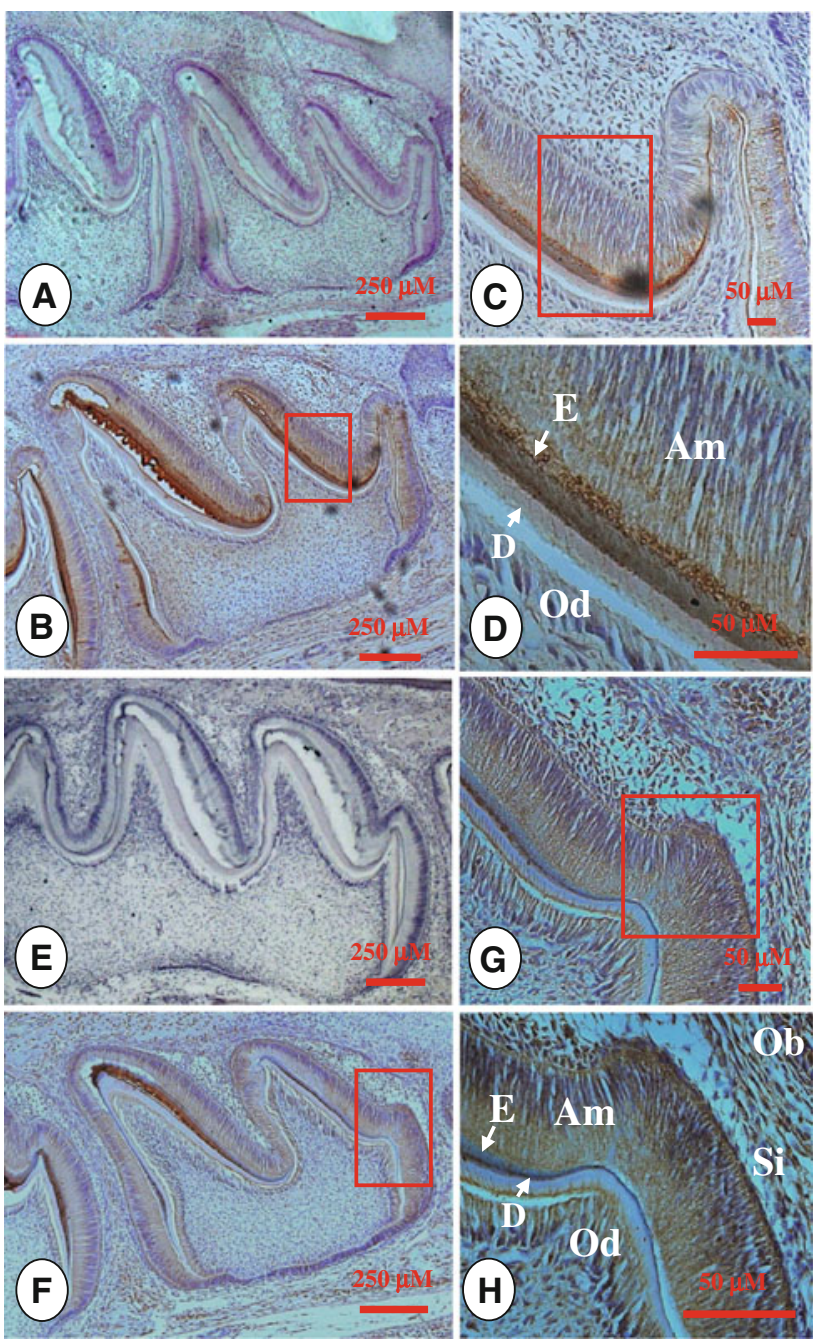

Fig. 2 Amelogenin and MMP-9 expression patterns at postnatal day 5 in developing teeth. $\mathbf{b}$ Expression of amelogenin protein was found in ameloblasts, enamel matrix and odontoblasts. c, d were higher magnification of the boxed area in b. a Pre-immune IgG at the same concentration as the anti-amelogenin antibody was used as a negative control. f Immunostaining indicated that MMP-9 was widely expressed in ameloblasts, odontoblasts and enamel matrix and other cells. $\mathbf{g}, \mathbf{h}$ showed higher magnification of the boxed area in $\mathbf{f}$. e Tissue section was incubated with pre-immune IgG as control. Am ameloblasts, $D$ dentin, $E$ enamel, $O d$ odontoblasts, $O b$ bone mesenchymal cells, $S i$ stratum intermedium

expression level in odontoblasts was much lower than ameloblasts and the enamel layer. MMP-9 signal coincided with the expression of amelogenin in ameloblasts, enamel layer as well as odontoblasts (Fig. 4c, g). However, the MMP-9 expression pattern was widely detected in other tissues besides ameloblasts, enamel matrix and odontoblasts. To further confirm their co-localization, tissue sections from PN4 were examined using the confocal microscope. The data showed that their co-expression was seen mostly within the cytoplasm of the ameloblasts (Fig. 4j). 


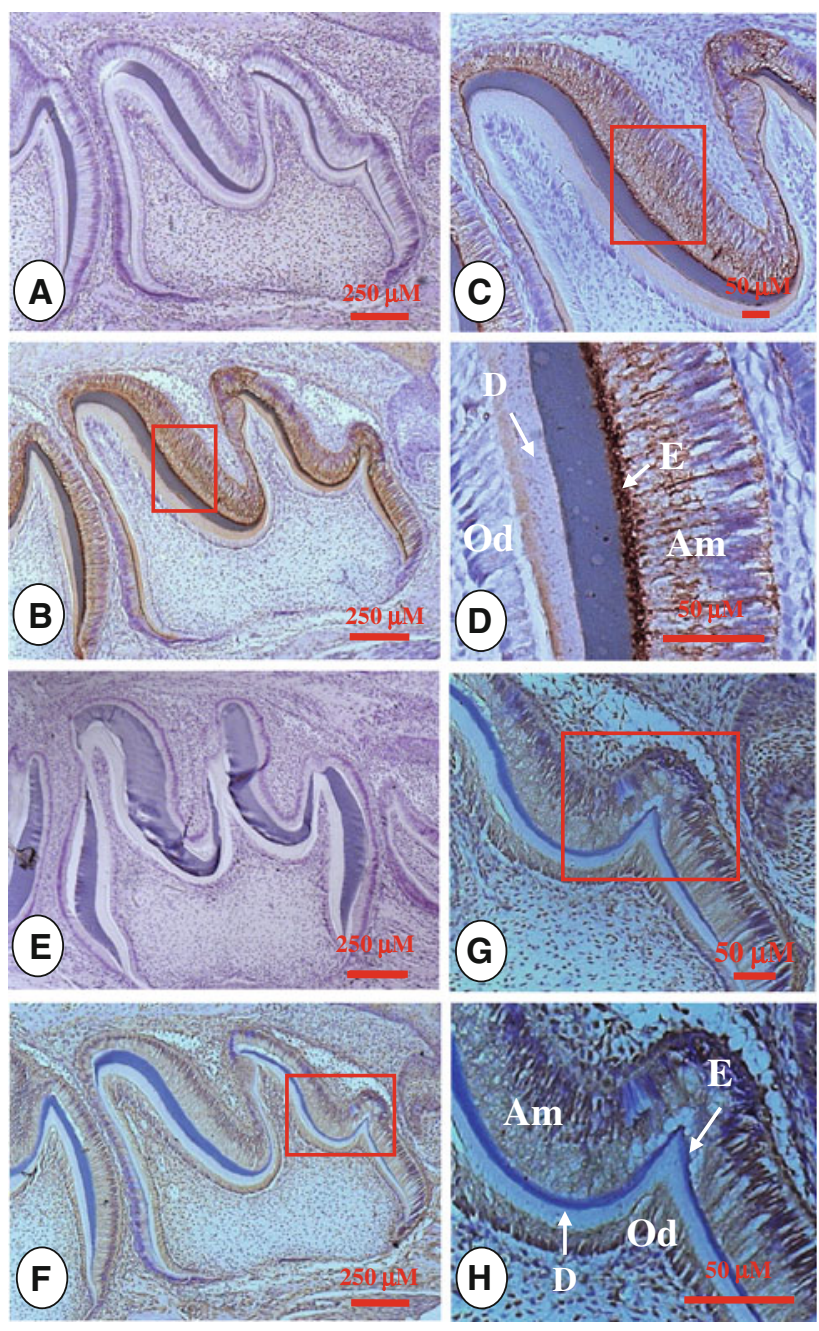

Fig. 3 Amelogenin and MMP-9 expression patterns at postnatal day 7 in developing teeth. Both amelogenin and MMP-9 were expressed in ameloblasts, enamel matrix and odontoblasts. $\mathbf{b}$. Tissue section was stained with anti-amelogenin antibody. c, d showed higher magnification of the boxed area in $\mathbf{b}$. Expression of amelogenin was detected in ameloblasts and the enamel matrix. Also, low levels of amelogenin were found in odontoblasts. a Negative control. f Immunostaining indicated that MMP-9 was widely expressed in other cells besides ameloblasts, odontoblasts and the enamel matrix. $\mathbf{g}, \mathbf{h}$ showed higher magnification of the boxed area in $\mathbf{f}$. e Tissue section was incubated with pre-immune $\mathrm{IgG}$ as a negative control. $A m$ ameloblasts, $D$ dentin, $E$ enamel, $O d$ odontoblasts

Expression of amelogenin and MMP-9 in mouse enamel organ epithelial and odontoblast-like cells

To assess amelogenin and MMP-9 expression in EOE-3M and MO6-G3 cells, RT-PCR analysis was performed using specific primers for amelogenin and MMP-9. Figure 5a showed that amelogenin and MMP-9 RNAs were identified in mouse tooth tissues, EOE-3M and MO6-G3 cells. Furthermore, their protein expression was detected by Western blot and enzymatic zymography assays, respectively (Fig. 5b, c). Immunohistochemical analysis demonstrated that those
Fig. 4 Co-expression of amelogenin and MMP-9 in developing teeth. Amelogenin expression was detected in pre-ameloblasts, ameloblasts, enamel matrix and odontoblasts. However, the highest level of expression was in secretory ameloblasts and the enamel layer $(\mathbf{b}, \mathbf{f}, \mathbf{i})$. Amelogenin protein was mostly located within the supra-nuclear area (towards the enamel) in secretory ameloblasts. MMP-9 was also expressed in these areas overlapped with amelogenin $(\mathbf{c}, \mathbf{g}, \mathbf{i}) . \mathbf{d}$, h The cells were stained with Hoechst for the nucleus. i Image was merged. Bar $=10 \mu \mathrm{M}$. j Confocal micrographs of collapsed z-projection images (consisting of $20 \mathrm{z}$-sections with spacing increments of $1 \mathrm{mM}$ ) show amelogenin (green color) and MMP-9 (red color) staining relationships within ameloblastic cells and enamel matrix of a tooth section from a postnatal day $4 . \mathbf{a}^{\prime}, \mathbf{b}^{\prime}$. Higher magnification of the boxed area in $\mathbf{j}-\mathbf{a}, \mathbf{b}$ : amelogenin expression was weakly detected in pre-ameloblasts at the cervical loop (Cp) region, but MMP-9 expression (red color) was seen within the cytoplasm in preameloblasts. Co-expression of amelogenin and MMP-9 proteins was visible within the cytoplasm of ameloblasts and in the enamel layer. High expression of amelogenin was observed in secretory ameloblasts $(\mathrm{Am})$ and enamel matrix (E)

proteins were expressed within the cytoplasm and cellular branches in EOE-3M and MO6-G3 cells (Fig. 4d-o).

MMP-9 binds to amelogenin in vitro

To determine binding of amelogenin to MMP-9, the recombinant amelogenin proteins from pET179 and pGST196 vectors were expressed in E.coli BL21 (DE3) cells. The crude extracts from sonicated cells were analyzed by SDS-PAGE to verify protein expression (Fig. 6a). The SDS-PAGE gel showed that the recombinant proteins, pET179 and pGST196, appeared at about 25 and $52 \mathrm{kDa}$, respectively. There was little sign of amelogenin expression in the un-induced cells. Following purification with glutathione beads of the pGST196 fusion protein, the recombinant amelogenin was resolved to near homogeneity as analyzed by SDS-PAGE gel (Fig. 6b) and further confirmed by Western blot analysis (Fig. 6c). For in vitro binding analysis, beads bearing either GST or pGST196 fusion protein were mixed with recombinant mutant MMP9 protein. After binding and washing, bound proteins were eluted from the beads. The eluted proteins were separated by a SDS-PAGE gel and electrotransferred to a trans-blot membrane for Western blotting assay. These results showed that beads bearing GST-amelogenin protein pulled down MMP-9, whereas beads bearing GST alone failed to bind to MMP-9 protein (Fig. 6d, e). This result indicates that the amelogenin binds MMP-9 in vitro.

\section{Prediction of MMP-9 cleavage site(s) in amelogenin}

Using computer software program, we searched for potential cleavage site(s) of MMP-9 in amelogenin across different species. The results show that the MMP-9 scissile bonds were found in amelogenin proteins across different species (Table 1). 

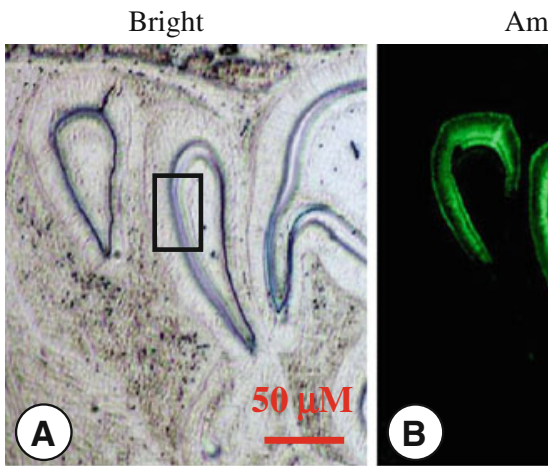

Amel

MMP-9

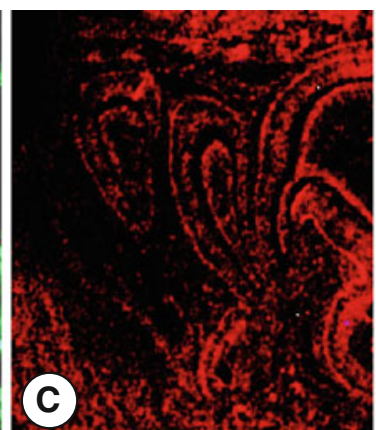

Amel
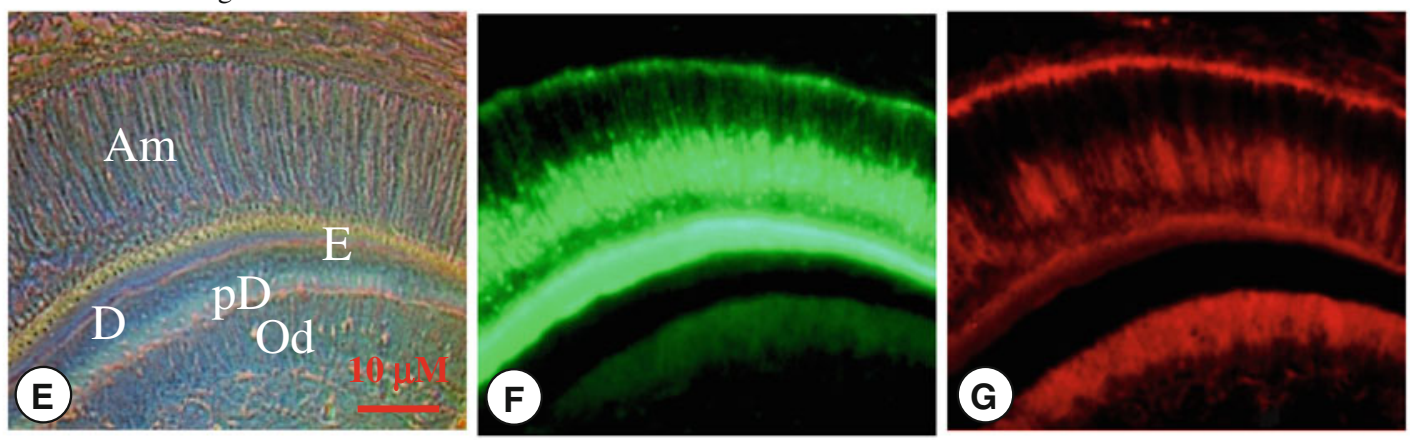

Merged
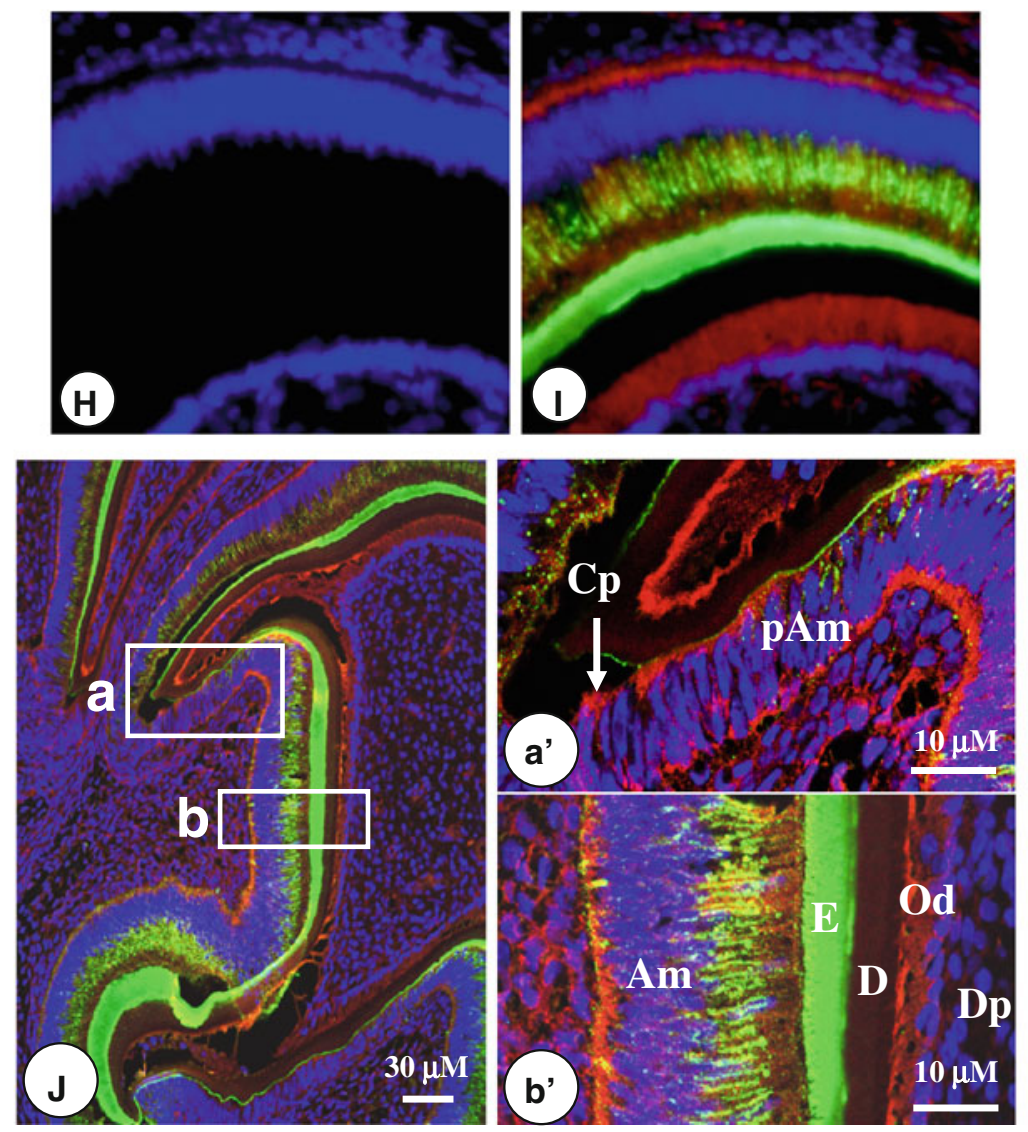
A
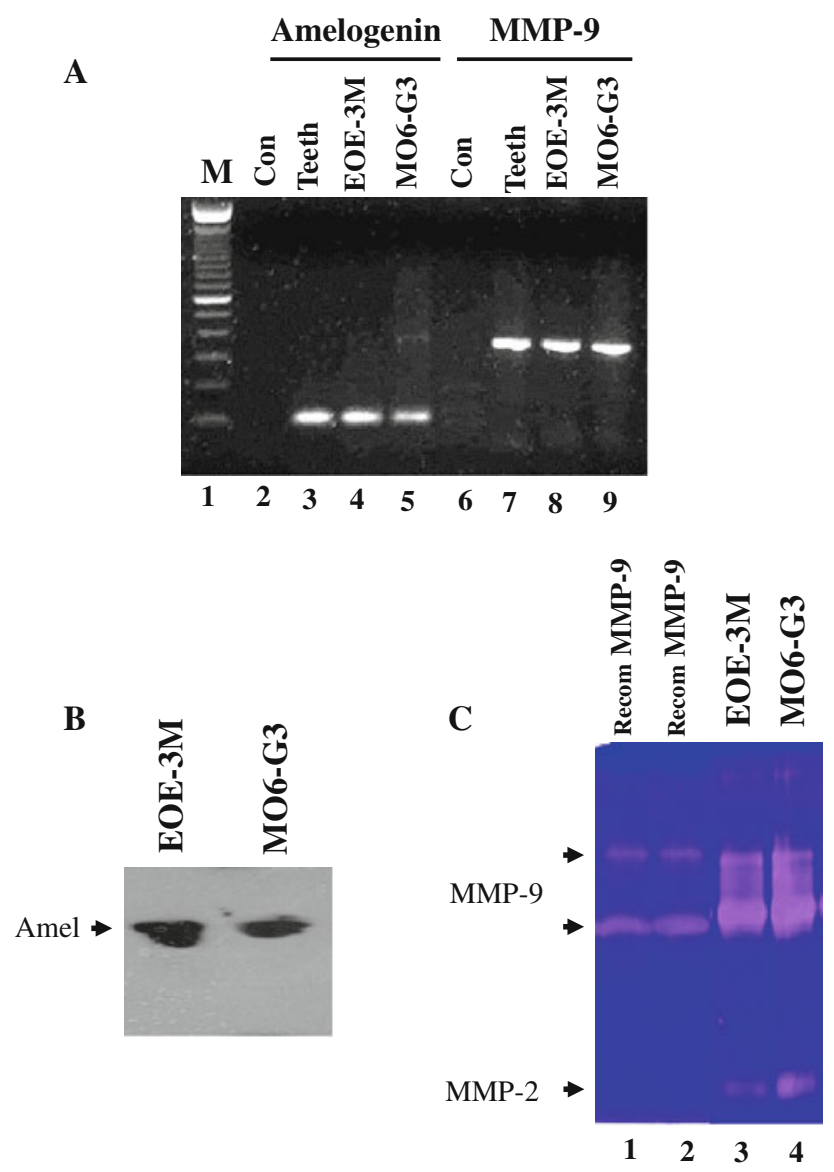

Fig. 5 Expression of amelogenin and MMP-9 genes in mouse enamel organ epithelial and odontoblast-like cells. a RT-PCR analysis of mRNA expression of amelogenin and MMP-9 genes from mouse tooth tissues, EOE-3M and MO6-G3 cells. RT-PCR products were run on a $1.5 \%$ agarose gel and stained with ethidium bromide. $M$ DNA marker. Lanes 2, 6 are the negative control. The PCR products are $91 \mathrm{bp}$ for amelogenin (lanes 3-5) and 348 bp for MMP-9 (lanes 7-9), respectively. b Expression of amelogenin protein in EOE-3M and MO6-G3 cells was performed by using Western blot analysis. Whole cell lysates were separated on a $10 \%$ SDSpolyacrylamide gel and electroblotted onto Trans-Blot membranes. The blot was probed with anti-amelogenin antibody and an arrow indicates a detected signal. c Gelatin zymography was used to detect MMP-9 protein. Lanes 1, 2 show recombinant mouse MMP-9 protein (R\&D Systems Inc.). Lanes 3, 4 were supernatant from EOE-3M and MO6-G3 cells without serum treatment, respectively. Recom MMP-9 indicates a recombinant mouse MMP-9 protein. d-o Expression of amelogenin and MMP-9 proteins in the EOE-3M and MO6-G3 cells was analyzed by immunostaining with either primary anti-amelogenin $(\mathbf{f}, \mathbf{g}, \mathbf{l}, \mathbf{m})$ or anti-MMP-9 antibody $(\mathbf{h}, \mathbf{i}, \mathbf{n}, \mathbf{q})$. Negative control was shown in $\mathbf{d}, \mathbf{e}, \mathbf{i}$ and $\mathbf{k}$. Both amelogenin and MMP-9 signals were detected within the cytoplasm and cellular branches in EOE-3M and MO6-G3 cells

\section{Discussion}

Although amelogenin and MMP-9 expression during tooth development was described (Snead et al. 1988; Diekwisch et al. 1997; Sahlberg et al. 1999; Linsuwanont et al. 2002;
Goldberg et al. 2003), their co-expression patterns during mouse tooth development and the interaction between the two proteins have not been investigated. In the present study, we investigated the spatial distribution of amelogenin and MMP-9 during mouse tooth development using immunohistochemistry assays. Also, we tested the interaction between amelogenin and MMP-9. Our results showed that the spatial distribution of amelogenin and MMP-9 is co-localized in ameloblasts, enamel matrix and odontoblasts during mouse tooth development although their expression levels and temporal expression patterns sometimes varied during tooth morphogenesis. Furthermore, amelogenin is able to bind MMP-9 in vitro and the MMP-9 cleavage sites exist in amelogenin proteins across different species.

Amelogenin expression was identified in the enamel organ of mouse molars as early as the embryonic day 15 (Couwenhoven and Snead 1994) and its expression was still visible in maturation stage ameloblasts at postnatal day 14 in mouse molars (Hu et al. 2001) whereas MMP-9 signal was found both in the dental epithelium and the mesenchyme at the bud stage (embryonic day 12) of developing mouse teeth (Sahlberg et al. 1999; Goldberg et al. 2003; Yoshiba et al. 2003). At the postnatal stages of tooth formation, expression of MMP-9 and other MMP family members were present in the differentiating ameloblasts (Yoshiba et al. 2003; Fanchon et al. 2004; Bourd-Boittin et al. 2005; Paiva et al. 2009). We observed co-expression of both amelogenin and MMP-9 in presecretory ameloblasts, secretory ameloblasts and odontoblasts as well as stratum intermedium at postnatal days 2-7 in mouse molars. Amelogenin accumulation increases with the gradient of the ameloblast differentiation and reaches an apparent plateau at the secretory stage. For the MMP-9 gene, its expression overlapped with amelogenin, in addition to the osteogenic mesenchyme and dental pulp cells. At postnatal days 5 and 7, the MMP-9 expression profile was similar to that of PN 2. Low amelogenin expression levels were present in odontoblasts and stratum intermedium cells through the postnatal stages of tooth development. This evidence was further verified in mouse enamel organ epithelial (EOE-3M) and odontoblast-like (MO6-G3) cells. Previous studies indicated that amelogenin expression was not detected in odontoblasts and other cell types (Snead et al. 1988; Inai et al. 1991, 1996; Bleicher et al. 1999; Hu et al. 2001). However, recent studies have shown that amelogenin expression is present in odontoblastic cells using in situ hybridization, immunohistochemistry and RTPCR analyses (Oida et al. 2002; Papagerakis et al. 2003; Iacob and Veis 2006). Our results are in agreement with previous studies by other groups (Oida et al. 2002; Papagerakis et al. 2003; Iacob and Veis 2006). However, the biological roles of amelogenin in odontoblasts and stratum 

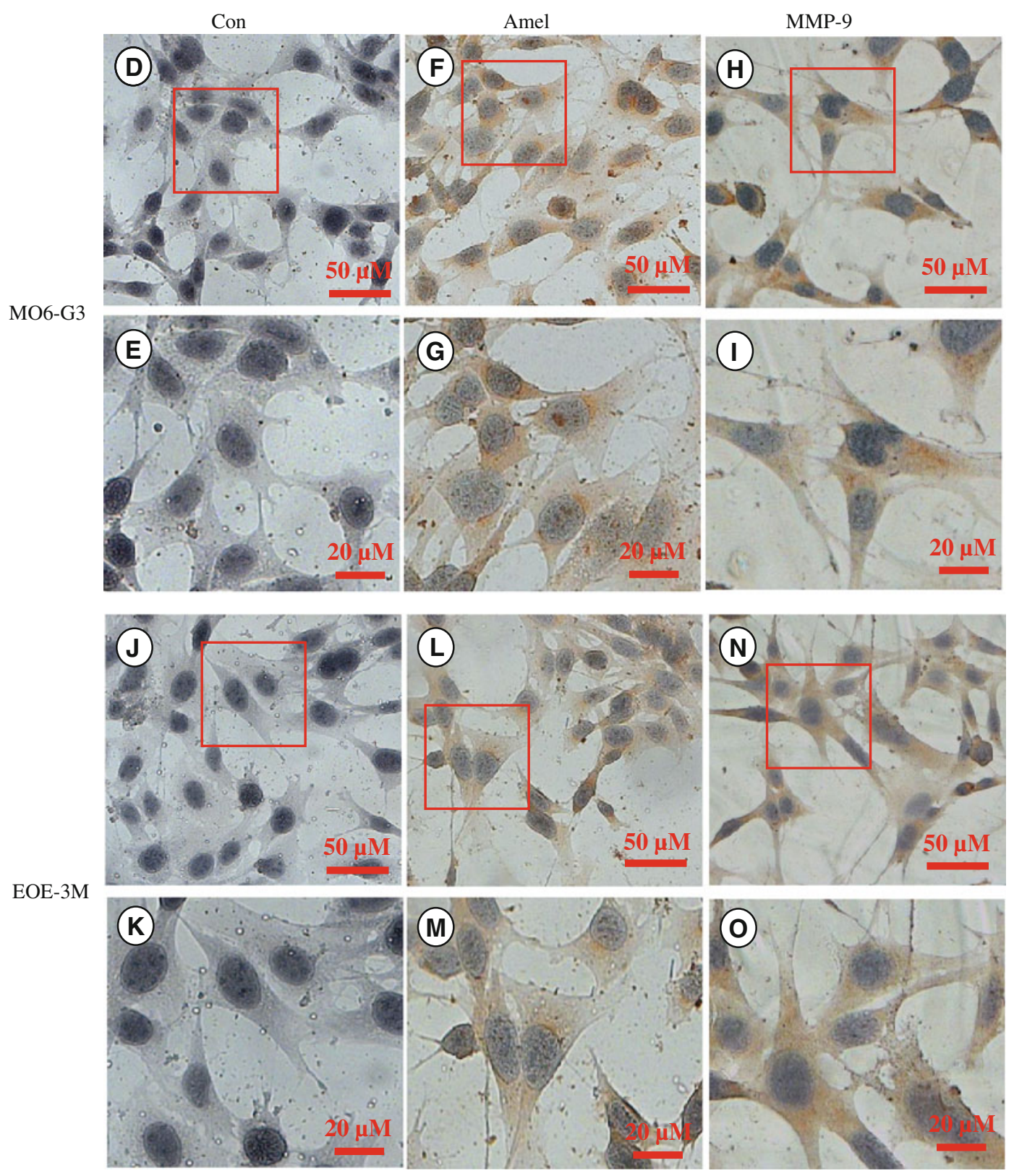

Fig. 5 continued

intermedium cells are not known. Besides co-expression of amelogenin and MMP-9 in ameloblast and odontoblasts, we further found that MMP-9 is able to interact with amelogenin, suggesting that amelogenin is a novel partner of MMP-9.

The amelogenin protein comprises about $90 \%$ of the enamel matrix proteins and has a range of molecular masses due to alternative splicing and proteolytic cleavage. Proteolytic processing of nascent amelogenin molecules serves to generate proper amelogenin fragments as enamel development proceeds (Fincham and Moradian-Oldak 1993; Bartlett and Simmer 1999). Studies have revealed that the $\mathrm{NH}_{2}$-terminal and $\mathrm{COOH}$-terminal domains of amelogenin proteins are essential for proper enamel formation (Gibson et al. 1991b; Le et al. 2007; Warotayanont et al. 2008; Nakayama et al. 2010; Pugach et al. 2010). In contrast, inappropriate processing of amelogenin by proteinases causes enamel defects (Caterina et al. 2002; Hart et al. 2004; Kim et al. 2005; Simmer et al. 2009).

MMP-9 is a member of the MMP family and has a broad range of substrates and mediates extracellular matrix remodeling (Kridel et al. 2001; Somerville et al. 2003; Lund et al. 2011). It is involved in normal physiological processes including bone remodeling and tooth eruption (Linsuwanont et al. 2002; Basi et al. 2011) and in pathological processes like periodontal disease (Rai et al. 2008; 

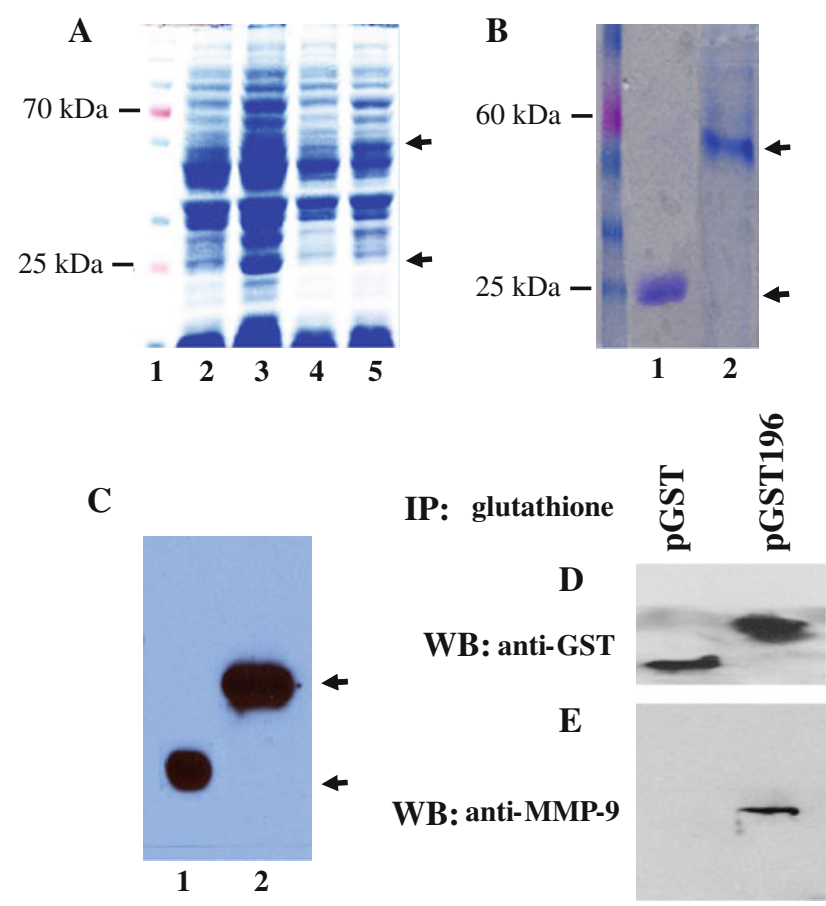

Fig. 6 Binding of amelogenin to MMP-9 in Vitro. a Coomassiestained SDS-PAGE gel for analysis of expression of untagged pET179 and pGST196 fusion proteins in DE 3 cells. Lane 1 molecular weight marker; lane 2 pET179 without $1 \mathrm{mM}$ IPTG induction; lane 3 pET179 with $1 \mathrm{mM}$ IPTG induction; lane 4 pGST196 without $1 \mathrm{mM}$ IPTG induction; lane 5 pGST196 with $1 \mathrm{mM}$ IPTG induction. All samples were grown $3 \mathrm{~h}$ either with or without $1 \mathrm{mM}$ IPTG induction after reaching OD600 of 0.6. Arrows show positions of expression of the recombinant amelogenin proteins. b SDS-PAGE analysis of purified pET179 (lane 1) and pGST196 (lane 2) fusion proteins from E. coli. extracts. c Expression of purified pET179 (lane 1) and pGST196 (lane 2) amelogenin proteins was confirmed by Western blotting analysis using goat polyclonal anti-amelogenin antibody (C19, Santa Cruz Biotechnology Inc.). d, e Either $5 \mu \mathrm{g}$ of GSTamelogenin fusion protein (pGST196) or $5 \mu \mathrm{g}$ of GST protein alone was mixed with the recombinant mutant MMP-9 protein in binding buffer (20 mM Tris-HCl, pH 8.0, $200 \mathrm{mM} \mathrm{NaCl}, 1 \mathrm{mM}$ EDTA) and followed by adding $20 \mu \mathrm{l}$ of glutathione-agarose beads for further incubation. After the binding reaction, the beads were washed twice with binding buffer and once with washing buffer. Beads were boiled in $1 \times$ SDS loading dye and the samples were divided into equal aliquots, and the eluted proteins were separated by SDS-PAGE and electrotransferred to the trans-blot membranes. Western blot assay was carried out using polyclonal anti-GST antibody (Amersham Pharmacia Biotech) (d) and polyclonal anti-MMP-9 antibody (Santa Cruz Biotechnology Inc.) (e)

Silva et al. 2008), dental caries (Chaussain-Miller et al. 2006; Shimada et al. 2009) and cancer invasion (Patel et al. 2011). In MMP-9 null mice, impairment of ossification and vascularization of the skeletal growth plates was observed (Vu et al. 1998). Skeletal growth plates of MMP-9 null mice in a culture system showed a delayed release of an angiogenic activator, establishing a role for this enzyme in controlling angiogenesis. Engsig et al. (2000) demonstrated that MMP-9 is essential for the recruitment of osteoclasts
Table 1 Identification of potential MMP-9 cleavage sites of amelogenin from different species

\begin{tabular}{llll}
\hline & $\begin{array}{l}\text { Peptide } \\
\text { sequences }\end{array}$ & References & $\begin{array}{l}\text { Genbank } \\
\text { accession } \\
\text { no. }\end{array}$ \\
\hline $\begin{array}{l}\text { MMP-9 } \\
\text { consensus }\end{array}$ & $\begin{array}{c}\text { P X X } \downarrow \text { Hy } \\
\text { S T }\end{array}$ & Kridel et al. 2001 & \\
Cow & P G Y $\downarrow$ I N & Iwase et al. 2003 & BAC66108 \\
Frog & P G Y $\downarrow$ V N & Toyosawa et al. & AAC78135 \\
Guinea & P G Y $\downarrow$ I N & Cerny 1998 & CAA09957 \\
Human & P G Y $\downarrow$ I N & Salido et al. 1992 & AAA51717 \\
Mouse & P G Y $\downarrow$ I N & Snead et al. 1985 & BAA06546 \\
Pig & P G Y $\downarrow$ I N & Iwase et al. 2003 & BAC66111 \\
Rat & P G Y $\downarrow$ I N & Li et al. 1995 & AAB03481 \\
\hline
\end{tabular}

$P$ proline, $H y$ hydrophobic amino acids, $S$ serine, $T$ threonine, $G$ glycine, $Y$ tyrosine, $I$ isoleucine, $N$ asparagine, $X$ any amino acids. Scissile bonds are shown with $\downarrow$

into developing bone. Our study found that mice lacking MMP-9 gene exhibit abnormal tooth morphology, immature ameloblast differentiation, loss of ameloblast polarization and delayed tooth eruption as well as an increased amelogenin expression during amelogenesis compared to the wild-type mice (Yuan et al. 2009 and unpublished data).

Amelogenin has been suggested as a possible substrate for MMP-9 due to the reciprocal concentrations of amelogenin and MMP-9 observed during tooth formation (Fanchon et al. 2004; Bourd-Boittin et al. 2005). Fanchon et al. used two MMP inhibitors, Marimastat, a general MMP inhibitor, or $\mathrm{CT}_{1166}$, a more selective inhibitor of MMP-2 and MMP-9, and found that when mouse tooth germs were treated with either Marimastat or $\mathrm{CT}_{1166}$, gelatinase activity was inhibited, resulting in disturbance of murine amelogenesis. This suggests that MMP-9 is involved in amelogenin processing and enamel development. However, although MMP-9 interacts with amelogenin in vitro and there are potential MMP-9 cleavage sites in amelogenin genes across species, whether MMP-9, like MMP20 and K1K4, is capable of catalyzing amelogenin and its role during amelegenesis needs to be further investigated.

Acknowledgments We are grateful to Dr. James Simmer (The Department of Biological and Materials Sciences, University of Michigan School of Dentistry, Ann Arbor, Michigan, USA) for providing the pET179 vector. This research was supported by grants from NIDCR RO1 DE019892 and NIDCR T-32 DE014318.

Conflict of interest The author(s) declared no potential conflicts of interest with respect to the authorship and/or publication of this article. 
Open Access This article is distributed under the terms of the Creative Commons Attribution License which permits any use, distribution, and reproduction in any medium, provided the original author(s) and the source are credited.

\section{References}

Aldred MJ, Crawford PJ, Roberts E, Thomas NS (1992) Identification of a nonsense mutation in the amelogenin gene (AMELX) in a family with X-linked amelogenesis imperfecta (AIH1). Hum Genet 90:413-416

Bartlett JD, Simmer JP (1999) Proteinases in developing dental enamel. Crit Rev Oral Biol Med 10:425-441

Basi DL, Hughes PJ, Thumbigere-Math V, Sabino M, Mariash A, Lunos SA, Jensen E, Gopalakrishnan R (2011) Matrix metalloproteinase-9 expression in alveolar extraction sockets of zoledronic acid-treated rats. J Oral Maxillofac Surg 69:2698-2707

Bleicher F, Couble ML, Farges JC, Couble P, Magloire H (1999) Sequential expression of matrix protein genes in developing rat teeth. Matrix Biol 18:133-143

Boabaid F, Gibson CW, Kuehl MA, Berry JE, Snead ML, Nociti FH Jr, Katchburian E, Somerman MJ (2004) Leucine-rich amelogenin peptide: a candidate signaling molecule during cementogenesis. J Periodontol 75:1126-1136

Bonass WA, Robinson PA, Kirkham J, Shore RC, Robinson C (1994) Molecular cloning and DNA sequence of rat amelogenin and a comparative analysis of mammalian amelogenin protein sequence divergence. Biochem Biophys Res Commun 198: 755-763

Bourd-Boittin K, Septier D, Hall R, Goldberg M, Menashi S (2004) Immunolocalization of enamelysin (matrix metalloproteinase20 ) in the forming rat incisor. J Histochem Cytochem 52: $437-445$

Bourd-Boittin K, Fridman R, Fanchon S, Septier D, Goldberg M, Menashi S (2005) Matrix metalloproteinase inhibition impairs the processing, formation and mineralization of dental tissues during mouse molar development. Exp Cell Res 304:493-505

Bronckers ALJJ, Bervoets TJM, Lyaruu DM, Wöltgens JHM (1995) Degradation of hamster amelogenins during secretory stage enamel formation in organ culture. Matrix Biol 14:533-541

Caterina JJ, Skobe Z, Shi J, Ding Y, Simmer JP, Birkedal-Hansen H, Bartlett JD (2002) Enamelysin (matrix metalloproteinase 20)deficient mice display an amelogenesis imperfecta phenotype. J Biol Chem 277:49598-49604

Cerny R (1998) Direct submission. Genbank accession number: CAA09957

Chaussain-Miller C, Fioretti F, Goldberg M, Menashi S (2006) The role of matrix metalloproteinases (MMPs) in human caries. J Dent Res 85:22-32

Chen S, Gluhak-Heinrich J, Martinez M, Li T, Wu Y, Chuang HH, Chen L, Dong J, Gay I, MacDougall M (2008) Bone morphogenetic protein 2 mediates dentin sialophosphoprotein expression and odontoblast differentiation via NF-Y signaling. J Biol Chem 283:19359-19370

Couwenhoven RI, Snead ML (1994) Early determination and permissive expression of amelogenin transcription during mouse mandibular first molar development. Dev Biol 164:290-299

Deutsch D, Catalano-Sherman J, Dafni L, David S, Palmon A (1995) Enamel matrix proteins and ameloblast biology. Connect Tissue Res 32:97-107

Diekwisch TG, Ware J, Fincham AG, Zeichner-David M (1997) Immunohistochemical similarities and differences between amelogenin and tuftelin gene products during tooth development. J Histochem Cytochem 45:859-866
Engsig MT, Chen QJ, Vu TH, Pedersen AC, Therkidsen B, Lund LR, Henriksen K, Lenhard T, Foged NT, Werb Z, Delaissé JM (2000) Matrix metalloproteinase 9 and vascular endothelial growth factor are essential for osteoclast recruitment into developing long bones. J Cell Biol 151:879-889

Fanchon S, Bourd K, Septier D, Everts V, Beertsen W, Menashi S, Goldberg M (2004) Involvement of matrix metalloproteinases in the onset of dentin mineralization. Eur J Oral Sci 112:171-176

Fincham AG, Moradian-Oldak J (1993) Amelogenin post-translational modifications: carboxy-terminal processing and the phosphorylation of bovine and porcine "TRAP" and "LRAP" amelogenins. Biochem Biophys Res Commun 197:248-255

Fong CD, Hammarström L, Lundmark C, Wurtz T, Slaby I (1996) Expression patterns of RNAs for amelin and amelogenin in developing rat molars and incisors. Adv Dent Res 10:195-200

Gibson C, Golub E, Herold R, Risser M, Ding W, Shimokawa H, Young M, Termine J, Rosenbloom J (1991a) Structure and expression of the bovine amelogenin gene. Biochemistry 30:1075-1079

Gibson CW, Golub E, Ding WD, Shimokawa H, Young M, Termine J, Rosenbloom J (1991b) Identification of the leucine-rich amelogenin peptide (LRAP) as the translation product of an alternatively spliced transcript. Biochem Biophys Res Commun 174:1306-1312

Gibson C, Yuan Z, Hall B, Longenecker G, Chen E, Thyagarajan T, Sreenath T, Wright J, Decker S, Piddington R, Harrison G, Kulkarni A (2001) Amelogenin-deficient mice display an amelogenesis imperfect phenotype. J Biol Chem 276:3187131875

Goldberg M, Septier D, Bourd K, Hall R, George A, Goldberg H, Menashi S (2003) Immunohistochemical localization of MMP-2, MMP-9, TIMP-1, and TIMP-2 in the forming rat incisor. Connect Tissue Res 44:143-153

Gomes JR, Omar NF, dos Santos Neves J, Narvaes EA, Novaes PD (2011) Immunolocalization and activity of the MMP-9 and MMP-2 in odontogenic region of the rat incisor tooth after post shortening procedure. J Mol Histol 42:153-159

Hart PS, Hart TC, Michalec MD, Ryu OH, Simmons D, Hong S, Wright JT (2004) Mutation in kallikrein 4 causes autosomal recessive hypomaturation amelogenesis imperfecta. J Med Genet 41:545-549

Haze A, Taylor AL, Blumenfeld A, Rosenfeld E, Leiser Y, Dafni L, Shay B, Gruenbaum-Cohen Y, Fermon E, Haegewald S, Bernimoulin JP, Deutsch D (2007) Amelogenin expression in long bone and cartilage cells and in bone marrow progenitor cells. Anat Rec (Hoboken) 290:455-460

Hu CC, Bartlett JD, Zhang CH, Qian Q, Ryu OH, Simmer JP (1996) Cloning, cDNA sequence, and alternative splicing of porcine amelogenin mRNAs. J Dent Res 75:1735-1741

Hu JC, Sun X, Zhang C, Simmer JP (2001) A comparison of enamelin and amelogenin expression in developing mouse molars. Eur $\mathrm{J}$ Oral Sci 109:125-132

Iacob S, Veis A (2006) Identification of temporal and spatial expression patterns of amelogenin isoforms during mouse molar development. Eur J Oral Sci 114(Suppl 1):194-200

Inage T, Shimokawa H, Wakao K, Sasaki S (1996) Gene expression and localization of amelogenin in the rat incisor. Adv Dent Res 10:201-207

Inai T, Kukita T, Ohsaki Y, Nagata K, Kukita A, Kurisu K (1991) Immunohistochemical demonstration of amelogenin penetration toward the dental pulp in the early stages of ameloblast development in rat molar tooth germs. Anat Rec 229:259-270

Iwase M, Satta Y, Hirai Y, Hirai H, Imai H, Takahata N (2003) The amelogenin loci span an ancient pseudoautosomal boundary in diverse mammalian species. Proc Natl Acad Sci USA 100:5258-5263 
Karg HA, Burger EH, Lyaruu DM, Wöltgens JH, Bronckers AL (1997) Gene expression and immunolocalisation of amelogenins in developing embryonic and neonatal hamster teeth. Cell Tissue Res 288:545-555

Kim JW, Simmer JP, Hart TC, Hart PS, Ramaswami MD, Bartlett JD, $\mathrm{Hu}$ JC (2005) MMP-20 mutation in autosomal recessive pigmented hypomaturation amelogenesis imperfecta. J Med Genet 42:271-275

Kridel SJ, Chen E, Kotra LP, Howard EW, Mobashery S, Smith JW (2001) Substrate hydrolysis by matrix metalloproteinase-9. J Biol Chem 276:20572-20578

Lagerström M, Dahl N, Nakahori Y, Nakagome Y, Bäckman B, Landegren U, Pettersson U (1991) A deletion in the amelogenin gene (AMG) causes X-linked amelogenesis imperfecta (AIH1). Genomics 10:971-975

Le TQ, Zhang Y, Li W, Denbesten PK (2007) The effect of LRAP on enamel organ epithelial cell differentiation. J Dent Res 86: 1095-1099

Li R, Li W, DenBesten PK (1995) Alternative splicing of amelogenin mRNA from rat incisor ameloblasts. J Dent Res 74:1880-1885

Li W, Machule D, Gao C, DenBesten PK (1999) Activation of recombinant bovine matrix metalloproteinase-20 and its hydrolysis of two amelogenin oligopeptides. Eur J Oral Sci 107: 352-359

Linsuwanont B, Takagi Y, Ohya K, Shimokawa H (2002) Expression of matrix metalloproteinase- $9 \mathrm{mRNA}$ and protein during deciduous tooth resorption in bovine odontoclasts. Bone 31:472-478

Lund IK, Nielsen BS, Almholt K, Rønø B, Hald A, Illemann M, Green KA, Christensen IJ, Rømer J, Lund LR (2011) Concomitant lack of MMP9 and uPA disturbs physiological tissue remodeling. Dev Biol 358:56-67

Morgunova E, Tuuttila A, Bergmann U, Isupov M, Lindqvist Y, Schneider G, Tryggvason K (1999) Structure of human promatrix metalloproteinase-2: activation mechanism revealed. Science 284:1667-1670

Nagano T, Oida S, Ando H, Gomi K, Arai T, Fukae M (2003) Relative levels of mRNA encoding enamel proteins in enamel organ epithelia and odontoblasts. J Dent Res 82:982-986

Nagase H, Visse R, Murphy G (2006) Structure and function of matrix metalloproteinases and TIMPs. Cardiovasc Res 69:562-573

Nakahori Y, Takenaka O, Nakagome Y (1991) A human X-Y homologous region encodes 'amelogenin'. Genomics 9:264-269

Nakayama Y, Yang L, Mezawa M, Araki S, Li Z, Wang Z, Sasaki Y, Takai H, Nakao S, Fukae M, Ogata Y (2010) Effects of porcine $25 \mathrm{kDa}$ amelogenin and its proteolytic derivatives on bone sialoprotein expression. J Periodontal Res 45:602-611

Oida S, Nagano T, Yamakoshi Y, Ando H, Yamada M, Fukae M (2002) Amelogenin gene expression in porcine odontoblasts. J Dent Res 81:103-108

Paiva KB, Zambuzzi WF, Accorsi-Mendonça T, Taga R, Nunes FD, Sogayar MC, Granjeiro JM (2009) Rat forming incisor requires a rigorous ECM remodeling modulated by MMP/RECK balance. J Mol Histol 40:201-207

Palosaari H, Pennington CJ, Larmas M, Edwards DR, Tjäderhane L, Salo T (2003) Expression profile of matrix metalloproteinases (MMPs) and tissue inhibitors of MMPs in mature human odontoblasts and pulp tissue. Eur J Oral Sci 111:117-127

Papagerakis P, MacDougall M, Hotton D, Bailleul-Forestier I, Oboeuf M, Berdal A (2003) Expression of amelogenin in odontoblasts. Bone 32:228-240

Patel S, Sumitra G, Koner BC, Saxena A (2011) Role of serum matrix metalloproteinase- 2 and -9 to predict breast cancer progression. Clin Biochem 44:869-872

Pugach MK, Li Y, Suggs C, Wright JT, Aragon MA, Yuan ZA, Simmons D, Kulkarni AB, Gibson CW (2010) The amelogenin
C-terminus is required for enamel development. J Dent Res $89: 165-169$

Rai B, Kharb S, Jain R, Anand S (2008) Biomarkers of periodontitis in oral fluids. J Oral Sci 50:53-56

Randall LE, Hall RC (2002) Temperospatial expression of matrix metalloproteinases $1,2,3$, and 9 during early tooth development. Connect Tissue Res 43:205-211

Ryu OH, Fincham AG, Hu CC, Zhang C, Qian Q, Bartlett JD, Simmer JP (1999) Characterization of recombinant pig enamelysin activity and cleavage of recombinant pig and mouse amelogenins. J Dent Res 78:743-750

Sahlberg C, Reponen P, Tryggvason K, Thesleff I (1999) Timp-1, -2, and -3 show coexpression with gelatinases $\mathrm{A}$ and $\mathrm{B}$ during mouse tooth morphogenesis. Eur J Oral Sci 107:121-130

Salido EC, Yen PH, Koprivnikar K, Yu LC, Shapiro LJ (1992) The human enamel protein gene amelogenin is expressed from both the $\mathrm{X}$ and the $\mathrm{Y}$ chromosomes. Am J Hum Genet 50:303-316

Shimada Y, Ichinose S, Sadr A, Burrow MF, Tagami J (2009) Localization of matrix metalloproteinases (MMPs-2, 8, 9 and 20) in normal and carious dentine. Aust Dent J 54:347-354

Silva JA, Lorencini M, Peroni LA, De La Hoz CL, Carvalho HF, Stach-Machado DR (2008) The influence of type I diabetes mellitus on the expression and activity of gelatinases (matrix metalloproteinases-2 and -9) in induced periodontal disease. J Periodontal Res 43:48-54

Simmer J, Lau C, Hu C, Aoba T, Lacey M, Nelson D, Zeichner-David M, Snead M, Slavkin H, Fincham A (1994) Isolation and characterization of a mouse amelogenin expressed in Escherichia coli. Calcif Tissue Int 54:319-321

Simmer JP, Hu Y, Lertlam R, Yamakoshi Y, Hu JC (2009) Hypomaturation enamel defects in Klk4 knockout/LacZ knockin mice. J Biol Chem 284:19110-19121

Snead ML, Zeichner-David M, Chandra T, Robson KJ, Woo SL, Slavkin HC (1983) Construction and identification of mouse amelogenin cDNA clones. Proc Natl Acad Sci USA 80:72547258

Snead ML, Lau EC, Zeichner-David M, Fincham AG, Woo SL, Slavkin HC (1985) DNA sequence for cloned cDNA for murine amelogenin reveal the amino acid sequence for enamel-specific protein Biochem. Biophys Res Commun 129:812-818

Snead ML, Luo W, Lau EC, Slavkin HC (1988) Spatial- and temporalrestricted pattern for amelogenin gene expression during mouse molar tooth organogenesis. Development 104:77-85

Somerville R, Oblander S, Apte S (2003) Matrix metalloproteinases: old dogs with new tricks. Genome Biol 4:216.1-216.11

Sun Z, Carpiaux W, Fan D, Fan Y, Lakshminarayanan R, MoradianOldak J (2010) Apatite reduces amelogenin proteolysis by MMP-20 and KLK4 in vitro. J Dent Res 89:344-348

Takagi T, Suzuki M, Baba T, Minegishi K, Sasaki S (1984) Complete amino acid sequence of amelogenin in developing bovine enamel. Biochem Biophys Res Commun 121:592-597

Takahashi I, Onodera K, Nishimura M, Mitnai H, Sasano Y, Mitani H (2006) Expression of genes for gelatinases and tissue inhibitors of metalloproteinases in periodontal tissues during orthodontic tooth movement. J Mol Histol 37:333-342

Tjäderhane L, Salo T, Larjava H, Larmas M, Overall CM (1998) A novel organ culture method to study the function of human odontoblasts in vitro: gelatinase expression by odontoblasts is differentially regulated by TGF-beta1. J Dent Res 77:1486-1496

Toyosawa S, O'hUigin C, Figueroa F, Tichy H, Klein J (1998) Identification and characterization of amelogenin genes in monotremes, reptiles, and amphibians. Proc Natl Acad Sci USA 95:13056-13061

Uskoković V, Khan F, Liu H, Witkowska HE, Zhu L, Li W, Habelitz S (2011) Hydrolysis of amelogenin by matrix metalloprotease-20 accelerates mineralization in vitro. Arch Oral Biol 56:1548-1559 
Veis A, Tompkins K, Alvares K, Wei K, Wang L, Wang XS, Brownell AG, Jengh SM, Healy KE (2000) Specific amelogenin gene splice products have signaling effects on cells in culture and in implants in vivo. J Biol Chem 275:41263-41272

Vu T, Shipley J, Bergers G, Berger J, Helms J, Hanahan D, Shapiro S, Senior R, Werb Z (1998) MMP-9/gelatinase B is a key regulator of growth plate angiogenesis and apoptosis of hypertrophic chondrocytes. Cell 93:411-422

Wakida K, Amizuka N, Murakami C, Satoda T, Fukae M, Simmer JP, Ozawa H, Uchida T (1999) Maturation ameloblasts of the porcine tooth germ do not express amelogenin. Histochem Cell Biol 111:297-303

Warotayanont R, Zhu D, Snead ML, Zhou Y (2008) Leucine-rich amelogenin peptide induces osteogenesis in mouse embryonic stem cells. Biochem Biophys Res Commun 367:1-6
Wright JT, Torain M, Long K, Seow K, Crawford P, Aldred MJ, Hart PS, Hart TC (2011) Amelogenesis imperfecta: genotype-phenotype studies in 71 families. Cells Tissues Organ 194:279-283

Xu X, Chen Z, Wang Y, Yamada Y, Steffensen B (2005) Functional basis for the overlap in ligand interactions and substrate specificities of matrix metalloproteinases-9 and -2. Biochem J 392:127-134

Yoshiba N, Yoshiba K, Stoetzel C, Perrin-Schmitt F, Cam Y, Ruch JV, Lesot H (2003) Temporospatial gene expression and protein localization of matrix metalloproteinases and their inhibitors during mouse molar tooth development. Dev Dyn 228:105-112

Yuan G, Yang G, Gonzalez O, Gluahk-Heinrich J, Xu X, Chen Z, Steffensen B, Donly K, MacDougall M, Chen Z, Chen S (2009) Tooth defects and DSP/DSPP processing interference in MMP-9 knock out mice. 89th general session \& exhibition of the IADR, pp 126 